\title{
Intimations of Precarity in Twenty-First-Century U.S. Drama: Faltering Voices of the Precariat in Annie Baker's The Flick ${ }^{1}$
}

Indicios de precariedad en el teatro estadounidense del siglo XXI: las vacilantes voces del precariado en The Flick, de Annie Baker

ANA FERNÁNDEZ-CAPARRÓS

UNIVERSITAT DE VALÈNCIA

ORCID: https://orcid.org/0000-0001-9484-6493

\begin{abstract}
While much critical attention as been devoted to the representation of precarity on the European stages, and in British theatre in particular, dramatic texts produced in the United States that concern, depict and represent the lives of members of the so-called precariat have barely been the object of critical scrutiny. This article traces the emergence of a growing concern with economic hardship in the second decade of the twenty-first century in American drama and presents a case study of Annie Baker's The Flick (2013). Baker's play is illustrative of an aesthetics of precarity that refrains from victimizing the members of the precariat and that plays out the paradoxes of scenarios of precarity as being at once troubling and enabling transformation and visions of possibility.
\end{abstract}

Key words: precarity, representations of crisis, 21st-century American drama, Annie Baker, The Flick.

RESUMEN: Mientras que la representación de la precariedad en el teatro contemporáneo europeo, y especialmente el británico, ha recibido en los últimos años una notable atención crítica, no es el caso de aquellas obras producidas en los Estados Unidos que se ocupan de la dramatización de las vidas de los miembros del llamado precariado. El siguiente artículo traza la emergencia de un creciente interés por cómo las adversidades económicas determinan los

\footnotetext{
${ }^{1}$ Research for this article was conducted at Basel University with the financial aid of a travel grant funded by the Program Estades curtes en altres universitats $i$ centres d'investigació (2019) of the University of Valencia.
} 
conflictos dramáticos en el teatro estadounidense de la segunda década del siglo XXI y presenta un análisis crítico de la obra The Flick, de Annie Baker (2013). La obra de Baker es representativa de una estética de la precariedad que se abstiene de victimizar a los miembros del precariado y que representa las paradojas de la precariedad como un escenario problemático pero que también puede propiciar transformaciones y nuevas visiones de posibilidad.

Palabras clave: precariedad, representaciones de crisis, teatro estadounidense del siglo XXI, Annie Baker, The Flick.

\section{INTRODUCTION: BRINGING PRECARITY CENTER STAGE}

Precarity emerged as a central concern in scholarly research and academic writing in the early twenty-first century as a "multi-stranded concept" (Kasmir, 2018) that describes and conceptualizes the unpredictability of the conditions of life within increasingly unstable cultural and economic terrains. The notion of precarity is related to the dramatic transformation that the global economy has undergone in the past four decades with "the globalization of the work force, the rise of automation, and-above all - the growth of Big Finance, Big Pharma and Big Tech" (Standing, 2018: 115) and it refers to the fact that much of the world's global population lacks stable work and steady incomes. Thus, informal, temporary or contingent work is "the predominant mode of livelihood in the contemporary world" (Kasmir, 2018). The term is generally used to identify a novel condition stemming from a distinctive phase of capitalist development associated with neoliberalism and which claims that precarization alters class relations and transforms collective identities and politics. The claim that precarity is a new phenomenon is not without its criticism, as risk, insecurity, danger of layoffs and wearisome conditions have more often than not affected labor workers in capitalist societies, not to mention the fact that in the heyday of national-scale expansion and extended social protections for citizen-workers in the twentieth century, whole segments of the population were "excluded from the hegemonic deal between capitalist corporations and large-scale unions" and thus "Fordist stability was largely the preserve of white men" (Kasmir, 2018). Significantly, however, the term precarity, defined as the "persistent uncertainty or insecurity with regard to employment, income, and living standards" (OED, "precarity" 2020) was only added as a new entry to the third edition of the Oxford English Dictionary in $2018 .^{2}$ Social-science research on precarity, in which the concept has generally a negative connotation and is used with quotation marks, started in the late 1990s with the seminal work of Pierre Bourdieu and Robert Castel, who established the fundamental analytical parameters for institutionalized precarization research used in the social sciences today (Lorey, 2015: 41). But as the concept has become elastic in the past two decades used as a "byword for life in late and later capitalism - or some argue, life in capitalism as usual" (Ridout and Schneider, 2012) and to describe "an affective atmosphere penetrating all classes" (Berlant, 2011: 201), it is

\footnotetext{
${ }^{2}$ While the first recorded usage in the entry of the noun precarity is of the year 1910, the adjective precarious appeared already in the first edition of the dictionary, with usage traced back to the seventeenth century.
} 
increasingly assumed that it does not refer to a passing or episodic condition but to "a new form of regulation that distinguishes this historical time" (Butler, 2015: vii) instead.

As a trope that extends beyond restrictive labels (Fragkou, 2019) across disciplines, precarity is currently associated with a set of terms, including precarious, precariousness, precarization and the precariat. These terms, however, bear different conceptual distinctions, and that is why Lorey distinguishes "three dimensions of the precarious: precariousness, precarity and governmental precarization" (2015: 11; her emphases). The first one, following Judith Butler, is the term for a socio-ontological dimension of lives and bodies. Butler (2004, 2012) conceptualizes precariousness as existential, relational, and unavoidable, in so far as all human beings are mortal, vulnerable to disease and accidents, and social. In the seminal Precarious Life, written in response to "to the conditions of heightened vulnerability and aggression" (Butler, 2004: xi) that followed the attacks of $9 / 11$, she advocated for a recognition of our ontological precariousness, that is, "our existence as bodily beings who depend upon one another for shelter and sustenance" (Butler, 2012: 148) as the basis to consider a dimension of political life where a community can be created from our exposure to violence and complicity in it, and from our vulnerability to loss and the mourning that follows it as a generalized human condition. Although precariousness is common to all, it is not equally shared because of its second dimension, precarity. Thus, precarity denotes "the striation and distribution of precariousness in relations of inequality" (Lorey, 2015) based on social hierarchies. Finally, Lorey claims that the third dimension of the precarious, governmental precarization, relates to modes of governing since the formation of industrial capitalist conditions, which means not only destabilization through employment, but also "destabilization of the conduct of life and thus of bodies and modes of subjectivation" (2015: 13).

Whereas pressing critical attention has been devoted in recent years to how theatre, as a public art, has negotiated, represented and captured the feeling of living in precarious times by interrogating the relationship between precarity and performance (Ridout and Schneider, 2011), and how British drama, in particular, responded to spiraling uncertainties and precarities (Adiseshiah and LePage, 2016; Aragay and Middeke, 2017; Angelaki, 2017; Fragkou, 2019), American theatre scholars have failed to engage critically with how American drama responded to a "social ecology of precarity" (Fragkou, 2019) in the twenty-first century in such a consistent way as European scholars. Christopher Bigsby claims in his Introduction to Staging America (2020) that in a cultural environment that lacks the British system of public subsidies, "the plight of the [American] playwright is as precarious as ever, even as the lure of a public art able to address audiences directly, collaboratively, visceral, the imagination made physical, words sounding in space, remain compelling" (2020: 2). Yet, whether the playwrights whose work he discusses, including Ayad Akhtar, Quiara Alegria Hudes, Bruce Norris, Stephen Adly Guirgis and others, have brought center stage precarious plights increasingly felt by a wider network of people is not specifically addressed. Bigsby's book was written before American theatre, like many other industries, had to handle the major crisis it has come across in the current century, caused by the economic impact of the coronavirus pandemic. Theatre has always been a "high wire act in which balance is not assured" (Bigsby, 2020: 2), but the ongoing shutdown has ruthlessly exposed the very precariousness and precarity on which the performative arts stand. The 51,000 actors and stage managers that The Actors Equity represents are still all virtually unemployed and some playwrights - who are among the few theatre industry workers who are not unionized - were even asked to refund payments for forthcoming cancelled productions, including the playwright whose work is discussed in this essay (Paulson, 
2020). Notwithstanding critical neglect, a close look at major, multi-awarded theatrical works produced in the second decade of the twenty-first century reveals that American playwrights had indeed shown, long before 2020, a keen awareness of what the current recession has only exacerbated and placed vividly and inescapably in front of everyone now, i.e. a dramatic escalation of the dire effects of the increasingly precarious dependence of life and work, which derives from the transformation of the latter "from stable, full-time jobs toward a flexible labour regime" (Kasmir, 2018) and is commonly identified as the shift from Fordism to post-Fordism.

\section{POST-CRISIS THEATRE AND THE HESITANT ENGAGEMENT WITH PRECARITY IN TWENTY-FIRST-CENTURY U.S. DRAMA}

The rising concern with economic hardship and precarization of lives in the United States cannot be separated from the financial crisis of 2008, an initially national subprime mortgage crisis that eventually introduced a global world to an era of bank failures, credit crunches, private defaults, and huge layoffs. It might be argued, in fact, that in the public sphere the confrontation with the structural inequalities that have grown with globalization was mainly coded through narratives of crisis, rather than conceptualizing it as precarity (Fernández-Caparrós and Brígido Corachán, 2017). As Lemke (2016) suggests, perhaps due to its negative connotations, the term precarity has not caught on in the United States, nor have the tenets of the new and expanding field of research and inquiry trickled down to the public. This might be related to the deeply ingrained belief in the U.S. of its exceptionalism, that is, the way its citizens define, sustain, and protect their national identity, based, within domestic affairs, on a view that heralds America as the land of opportunity and on being an exemplary democracy. This does not mean, in any case, that in spite of a general reluctance to use precarity as a conceptual tool, the nation should have been oblivious to the realities that the term describes. Significantly, when Barack Obama won the 2008 United States presidential elections and addressed the nation in his inaugural speech on January 20 2009, he explicitly stated that it was well understood that the U.S. were then "in the midst of crisis" (Obama 2009: par 1). He referred to a series of facts subject to data and statistics as clear indicators of crisis: being at war against a far-reaching network of violence and hatred; shuttered businesses, lost homes, shed jobs and an economy badly weakened as consequence of greed and irresponsibility on the part of some - but also of collective failure to make hard choices and prepare for a new age. Less measurable but no less profound was "a sapping of confidence across our land; a nagging fear that America's decline is inevitable, that the next generation must lower its sights." (Obama, 2009: par.4-5).

Obama's speech, interestingly, signals a shift in focus within post-millennial narratives of crisis in the U.S. from those events that had served as a defining moment in the contemporary American political, social, and cultural imagination at the turn of the millennium - the terrorist attacks of 9/11/2001 and the ensuing wars of Afghanistan and Iraq - to the effects that a severe financial crisis and economic recession had on material conditions of living and life expectations. Five years later, in his speech on Economic Mobility, he would further identify a "dangerous and growing inequality and lack of upward mobility" as jeopardizing "middle-class America's basic bargain - that if you work hard, you have a chance to get ahead" (Obama 2013: par.5). An overview of the drama produced in the twenty-first century in the United States reveals that the financial crisis of 2008 and the subsequent economic recession also served as a turning point in the way theatre responded to a changing political and socio-economic climate. Loss, fear, mourning, and violence, key issues in Butler's exploration of precariousness, are an 
underlying force in the dramatic literature of the early twenty-first century in the United States. Major plays by Sarah Ruhl (Eurydice, Dead Man's Cell Phone); Quiara Alegría Hudes (Eliot, A Soldier's Fugue; Water by the Spoonful); Christopher Shinn (Dying City); Rajiv Joseph (Bengal Tiger at the Baghdad Zoo) and Naomi Wallace (No Such Cold Thing) create a body of 'theatre of mourning' populated by ghosts and journeys to the afterlife. In these plays dealing with war, bereavement and memory, stage worlds are stark yet open and fluid to allow for the conflation of liminal planes of reality and for the blurring of boundaries between the world of the living and the world of the dead. Unlike this intensely metaphysical American drama of the first decade of the new millennium, the theatre of the second decade, with its attention "to the 'here and now' social realities of a recognizable world" (Aston 2016), became instead distinctly realistic and this formal and aesthetic turn can be seen as expressive of the growing awareness of that dimension of the precarious (Lorey, 2015), precarity, that serves to foreground the "material conditions that facilitate and maintain the uneven distribution of vulnerability and management of precarious life" (Fragkou 2019: 6). Among the plays that explore and negotiate the human costs exacted by job losses, declining wages and "the interpersonal devastation caused by the collapse of the American industry" (Mohler; McMahon and Román, 2016: 79) the following shall be singled out: Lisa D'Amour's Detroit (2010); Annie Baker's The Aliens (2010) and The Flick (2013); Stephen Karam's The Humans (2014); Lynn Nottage's Sweat (2015) and Martina Majok's Cost of Living (2016). Three of them were awarded the Pulitzer Prize for Drama: The Flick in 2014, Sweat in 2017, and Cost of Living in 2018. While none of them depict extreme poverty, all of them dramatize in different ways the private and public anxieties derived from dissolving assurances in regards to upward mobility, home ownership, job security, social and political equality, and meritocracy.

When looking at these plays one is struck by the fact that, as different as these theatrical works are, their characters - except initially those in Lynn Nottage's Sweatcould all be said to share a unifying feature: falling under the description of an emergent class, the precariat, a "new class mass defined by unstable labour arrangements, lack of identity and erosion of rights" (Standing, 2018: 115) that prevents them to have a sense of themselves as having a career trajectory. As Lemke (2016: 15) notes, this heterogeneous group is made up of a wide range of people of different ethnicities, ages, abilities and genders: "the self-employed, the temporarily employed, the full-time working poor, care workers, creative workers, adjunct academics, welfare recipients, migrants, and the homeless". Detroit brings together two (white) suburban couples and, of all the characters, only Mary, a paralegal, has a steady though precarious employment. Her husband is a bank loan officer recently laid off, whereas Kenny and Sharon, their next-door neighbors, work at the beginning of the play as warehouse manager and as a costumer-service call attendant at a phone bank, but are both fired before the end of the play. Likewise, in Karam's The Humans, which takes place in one-real time scene as the Blakes gather for a Thanksgiving at daughter Brigid's still unfurnished rented place in New York's Chinatown, all family members eventually confess to being under great economic distress. Both these plays address faltering housing aspirations and residential property as no longer financially attainable. Thus houses befallen by dilapidation visually exemplify the very fragility of owning property, which is, these plays insist, more virtual than real (Faisst, 2017).

Dramatic characters' sudden or gradual acknowledgement of their own economic and existential vulnerability in the plays above more often than not is disclosed subtly, quietly and almost apologetically. Precarity is intimated, never confronted candidly, at times silenced. In Karam's The Humans, for instance, there are many instances of 
dialogue in brackets that is expressed nonverbally. They are confessions of personal failure in the script that actors do not utter, as when Brigid tells her sister: "Uh, the restaurant pays me under the table so I can still collect unemployment, so that's been good...but...my career is [nonexistent]... [I don't wanna tall about it]" (Karam, 2015: 78). Only Lynn Nottage's Sweat, in its historic exploration of the disenfranchisement of blue-collar workers, overtly addresses governmental precarization and points to the neoliberal demolition and restructuring of the collective security system of unions as a tragic event. Given its reliance on the structure of classical tragedy as a most suitable framing to understand the interplay between human responsibility and outside forces governing our fate, the play was unambiguously perceived as insisting on the fact that the "loss of employment and the fear of poverty are tragic" (Mohler; McMahon and Román 2016: 94). On the contrary, the plays of Karam, Baker and D'Amour depict the often precipitous and enforced adjustment to the transformations brought about by the dissolution "of optimistic objects/scenarios that had once held the space open for the good-life fantasy" (Berlant, 2011: 3) in a more indirect way, veering to understatement instead. Charles Isherwood (2012) described the work of this new generation of playwrights as a theatre that depicts "the flux of life as most of us experience it: not splashy scenes of conflict and discord, but quiet, daily, almost trivial interactions through which we come together and grow apart." I would add, to Isherwood's insightful description, that these plays reveal also a very meticulous depiction of precarious lives whose perception requires arts of noticing for which old toolkits no longer work. As Anne Allison (2016) argues, "we need to see life in different terms to understand the ways it breaks down but also grows anew amidst the blasted ruins of capitalism". The way these playwrights show characters adapting to unfolding change is concomitant with an understanding of systemic crisis that is not exceptional to history or consciousness but rather "a process embedded in the ordinary that unfolds in stories about navigating what's overwhelming" (Berlant, 2011: 10).

In order to analyze the representational strategies and affective devices deployed to invite audiences to care about lives informed by neoliberal restructuring this essay zooms in on Annie Baker's The Flick as being arguably the most illustrative depiction on the contemporary American stage of labor precarity within a working environment and also, following Lemke (2016), a "precarious text" itself. The "remarkably tepid and lapidary" (Butler 2014: 179) description of the play on the Pulitzer Prize website describes it as "a thoughtful drama with well-crafted characters that focuses on three employees of a Massachusetts art-house movie theate rendering lives rarely seen on the stage" ("Drama", 2020). The playwright has referred to the fact that having a black guy, a woman, and a Jew, although Sam's Jewishness is not obvious, was important to her when she started writing the play: "Three of the great 'Others' of American cinema, all of them victim to extreme stereotypes. And yet what are Hollywood movies without blacks, Jews, and women? I wanted these people to be quietly (maybe even unconsciously) fighting against their respective pigeonholes" (Healy, 2013). While one might agree with Baker that it is rare to encounter "lower-middle-class Jews, hypereducated black people, and women who wear baggy clothes and no makeup" (Healy, 2013) in American plays and movies, it is my contention that what is also quite unique about her play is that it confronts audiences with the economic underworld of American life and with "economic subalterns" (Lemke, 2016: 6) that are seldom given a voice. While the play was not deliberately conceived as an overt exploration of the trials and tribulations of the precariat, in its exploration of the contemporary moment from within that moment, and as an "aesthetically mediated affective response" (Berlant, 2011: 3) to it, it shall be regarded as a dramatic text that most truthfully depicts the "distinctive 
relations of production (patterns of labour and work)" (Standing 2018: 117) proper of a new class; and how precarization affects interpersonal intercourse and can erode the sense of trust and community. As it will be shown, relying on dramatic analysis and on the work of cultural critics that have examined precarity in American culture (Berlant, 2011; Lemke, 2016), The Flick, like most American drama concerned with the precarization of livelihoods, plays out the paradoxes of precarity as a reality that can be at once troubling and enabling (Fragkou, 2019: 7) and is a theatrical text that ultimately resists a representation of precarity as 'crisis' thus avoiding participation in conservative discourses that normalize it as a threat.

\section{A SPACE FOR THE AUDIENCE OF THE PRECARIOUS IN ANNIE BAKER'S THE FLICK}

The set of The Flick reproduces a "raked movie theater audience" (Baker, 2014: 5 ) with ten to fifteen rows of red seats with a dingy carpeted aisle running up the center. The upstage wall is the back wall of the movie theatre, with a window into the projection booth and a metal door leading out into the unseen hallway to the movie theatre lobby (Baker, 2014: 5). Baker, a confessed cinephile, wanted to explore the overlooked transition of cinemas from projecting $35-\mathrm{mm}$ celluloid film to becoming venues that project digitally and write an ode to the vanishing art of going to the movies. She began with the idea of turning the fourth wall into (an invisible) movie screen (Bigsby, 2017:19). The set that she concocted, "a standoff, a confrontation, between film and theatre, audience seats vs. audience seats" (Yue, 2016: 63) creates a simple and ingenious mismatched mirroring device that visually enhances the intensely metacinematic and metadramatic features of a play where no single cinematic image is ever shown but dozens of cinematic references are evoked intermedially through dialogue and sound. All the scenes take place in the unoccupied stalls that echo those in the first frames of Buster Keaton's 1924 silent black-and-white Sherlock Jr. —one of the films Baker has identified as an influence (Piepenburg, 2013).

The play begins in a simple, extraordinary way with a flickering beam of white light from the projector on the back wall that dazzles the audience in the darkness, while the prelude of Bernard Herrmann's soundtrack of The Naked and the Dead is heard in the dark. Sarah Larson wrote in The New Yorker: "We hear drums, horns, pounding, the cadence of a march. We're not watching a movie-we're sitting in the dark, imagining one. It conjures thoughts of the Second World War, the twentieth century, the grand way of doing things in the past, the movies" (2015; her emphasis). But when the house lights of the theatre automatically flicker on, the privately envisaged visions and icons from the classic cinematic repertoire that linger on the spectators' minds stand in strong contrast to what is then actually displayed on the stage: the seemingly inconsequential working routines of two ushers, Sam and Avery, and a projectionist, Rose, after the movies are over. As the play opens, Sam, a 35-year-old Caucasian man with shaved head, is teaching the newly-employed Avery, a twenty-year-old bespectacled African-American man "in love with the movies" (Baker, 2014: 5), the best way to proceed, row after row of seats, with the sweeping up of popcorn kernels. Nothing much seems to happen in subsequent scenes of the first act: the two men wearing "the same degrading movie theatre uniform in very scene" (Baker, 2014: 5) are seen handling push brooms, dustpans, a large yellow mop bucket on wheels and casually chatting. Baker has said that for most of the play, her characters in The Flick "are just shooting the shit" (Bigsby, 2017: 21), and indeed, one of the most powerful things about her dramatic text is that, within the precarious working scenario depicted, where life and work are intimately connected, this idea goes beyond 
idle chatting to become fully literalized, made visible in the menial work these guys do, which is no other thing than serving others trashy food and then cleaning their crap up. Most of Sam and Avery's dialogue naturally revolves around dealing with waste: how to get rid of little pieces of lettuce, Subway sandwich wrappers, spilled drinks or how to clean soda machines overnight. Often, while sweeping, they entertain themselves playing a variant on the Six Degrees of Separation game: Sam names two actors and Avery has to connect them referring to films in as few moves as possible. As Yue (2016) suggests, their game is a fitting metaphor for the play's meandering structure.

To watch Baker's work "is to be drawn into a world that feels as unplotted as real life" (Heller, 2013) but that is, on the contrary, meticulously controlled by the playwright and conscientiously choreographed on the stage by director Sam Gold, Baker's long time collaborator in craftily formalizing the invisible precision that has become the hallmark of their theatrical style. Baker's The Flick and most of her previous plays are, formally, much indebted to the innovations of Chekhov, the only playwright whose influence she has explicitly acknowledged. Like her predecessor, Baker moves events to the periphery, as if they were details, and brings the ordinary, the constant and the recurring center stage, emphasizing progression in time, rather than in action, by providing spectators with great specificity of detail. Leslie Kane claims that

the seemingly formless Chehkhovian form is a meticulously constructed dramatic composition stripped bare of the lines of construction to convey naturally the desired effect of fluidity and fixity. Lacking in intrigue, complication, climax, and denouement, the mature plays are a sequence of scenes wherein spatial arrangement supplants linear arrangement and unity of mood supplants unity of action

(Kane, 1984: 51)

This description would equally apply to The Flick. Then, like Berlant, Baker shows "the ordinary as an impasse shaped by crisis in which people find themselves developing skills for adjusting to newly proliferating pressures to scramble for modes of living on" (2011: 8 ). On the page and on the stage, Baker masterfully recreates a style of communication built on constant understatement and dissociation from authenticity and deep feeling in the form of irrelevant small talk crafted in "a carefully pared down language of 'cools', 'likes', 'whatevers"' (Cayer, 2011: 39) that seemingly conceal the possibility of addressing any serious matter. Baker is a dramatist "who listens to people so carefully, who recreates human speech with such amusement and care, that her characters feel startingly familiar" (Larson, 2015). When she was seventeen, she started surreptitiously tape-recording people's conversations and transcribing them, an activity whose result, reading the conversations on paper, brought an uncommon awareness of how people speak their minds but also, and crucially, how the fail to do so, as all "the filler, the obliqueness and the false starts" (Larson, 2015) show. As Bigsby notes, "Baker works by indirection" (2017: 22) and buried in the ordinary speech, blank silences, random conversation and accumulation of detail, a portrait is slowly built and we perceive that "behind the daily banter, the jokes, there are thwarted hopes, anxiety and pain" (Bigsby, 2017: 22).

When The Flick opened Off-Broadway at Playwrights Horizons in New York City in February 2013, an unexpected controversy stirred up. During the first week of performances, about ten percent of the audience bolted the play at the interval (Healy, 2015). Some spectators were apparently infuriated by the play's over three-hour length, slow pace and extended silences and, as some walking out at intermission even threatened to cancel their subscriptions, artistic director Tim Sanford had to take the unprecedented step, ever since he took up his post in 1996, of emailing 3,000 theatre subscribers to explain his decision to produce Baker's play and defend her artistic integrity. This minor 
"flutter of a scandal" (Hoby 2016) could be merely regarded as just another theatrical anecdote, for neither the Playwrights Horizons' reputation as a theatrical institution nor Annie Baker's recognition was ever threatened by the initial polarized reactions to the show, both positive and negative. In terms of audience response, it foregrounds in fact that a performative event is what Erika Fisher-Lichte defines as an "autopoetic process" (2016: 164), in other words, that it is always an unfinished product whose course cannot be entirely planned or predicted, and that viewing in the theatre is a contingent, reciprocal, interactive process, always open "to immediate public acceptance, modification or rejection by those people it addresses" (Bennett, 1990: 72). And yet, it raises many questions as to whether a slowed-down performance and long silences were the only thing maddening some watchers and mesmerizing others. Lengthy theatre is nothing new, nor it is the "language of silence"- to use the title of Leslie Kane's 1984 classic study, whose analysis of the work of Maeterlinck, Chekhov, Bernard, Beckett, Pinter and Albee proves that silence is a structural element of modern drama. However, was it only how dramatic action is enacted on the stage that some people found annoying, boring, disturbing, unexciting, tedious or otherwise exhilarating? Or was what is shown on the stage as pressing in fostering strong emotional reactions? I want to argue that Baker's invitation to a heightened spectatorial engagement by reclaiming the etymological meaning of the word audience, which derives from Latin audire, and her plea for a prolonged listening to the faltering voices of the precariat shall not be regarded as independent phenomena. As Lemke notes, "an artistic representation of the social conditions that define the daily reality of millions does not usually gain mainstream visibility" (2016:20) and if this play either reached an essentially bourgeois audience of economically secure subscribers or failed to bridge communication across the class divide, it might be also to a great extent related to what it shows: the precariously uncertain lives of workers restraining from morally judging their (under)achievements and the seemingly foreclosed upward class mobility ahead of them.

The Flick is quite remarkable, as Wolcott (2015) notices, for how much of the outside world it is able to evoke from "its precarious womb of drab overhead light and cinematic dark, a socioeconomic landscape of low wages, low expectations and dim prospects even for those lucky enough to have a college diploma" and this feature of the play deserves critical attention. In Scene Four of Act One, Avery casually asks:

AVERY. Hey...

What do you wanna like.... What do you wanna like be when you grow up?

(pause)

SAM. ... I am grown up.

AVERY. Oh.

Yeah. I guess I just mean /like-

SAM. That's like the most depressing thing anyone's ever said to me.

AVERY. Sorry.

(Baker, 2014: 29)

While Avery's question is not judgmental, it points to the fact that a job that he, like most people, expects to be only temporary youth occupation has become the sole working option for many older workers. Sam's frustration and discontent had already transpired earlier on in Scene Two, where, because of Avery's late arrival and the stress of having to do "soda and a make a whole batch of popcorn" by himself, "unable to help himself", he confesses to his new fellow usher:

SAM. I'm just like-I don't know why Steve doesn't fucking promote me. I'm so sick of this shit.

(AVERY nods, a little confused) 
SAM. I should be a fucking projectionist by now!

AVERY. Oh. Yeah. I'd love to do that.

SAM. Well, he'll probably promote you before he promotes me. [...] He promoted Rose and I've worked here five months longer than her.

(Baker, 2014: 14)

In the excerpt above, as relevant as Sam's sense of humiliation, which a precarious existence usually entails (Lemke, 2016: 14) is Avery's confusion at it. Baker has referred to the fact that the young film buff she envisioned "came from both a different race and class background than the other characters in the play" (Healy, 2013). In fact, Avery, we later learn, is a student taking a break from Clark College, and his main reason to be working at The Flick is that it is the only theatre in Worcester County that still uses a Century film projector, which, for movie aficionados like him, "is an honor" (Baker, 2014: 93). While camaraderie grows between the two men, in spite of their age, race and class difference, the latter will eventually determine the outcome of the emerging conflict in Act Two. For, indeed, amid a deceptive lack of action, a dramatic conflict eventually arises and leads to plot resolution, at whose origins is the very precarity defining these characters' employment. In Scene Three, when Avery meets Rose, "Dinner Money" is mentioned. Unlike the per diem Avery expected it to be, this is the euphemism used instead for the small scam the characters run to augment their insufficient wages "because 8.25 an hour is not enough lo live on" (Baker, 2014: 24; her emphasis): in other words, the daily allowance they grant for themselves under the table. As Sam clarifies, they take about ten percent of the stubs from torn tickets and resell them to get ten percent of the cash for the night, which they use for buying dinner. Rose describes it hesitantly as being "like a like a like an employee tradition?" (Baker, 2014: 24) a former employee instructed them in, and which they justify by the fact that they are "vastly underpaid and because Steve is a total douchebag and doesn't have a credit card machine and is like totally fishy anyway with his finances and basically has no idea how to run a movie theatre" (Baker, 2014: 24).

'Dinner Money' in The Flick might be the clearest instance of the condition of dependency at the root of precarity. Yet the precarious relationship characters have with an always unseen boss supplying meager wages is then rendered even more fragile by the sly way they try to overcome their condition of suppliants that "hold only a tenuous right to what belongs to another person" (Lemke, 2016: 14) at the core of the etymological meaning of the adjective precarious. Avery is reluctant to being part of this scheme because he senses that, should they be unmasked, he might be in the most vulnerable position of them all "as a black guy" (Baker, 2014: 25). In spite of Avery's ethical concerns, he eventually gives in because the pressure to be "cool" with it is stronger than the otherwise precarious argument defended by Rose in the name of fairness and equality: "Listen. / Avery. / I don't want to be like a total cunt about this and I don't want to put you in a crappy position. / But if me and Sam are doing it and you're not it's like...it's like not fair to anybody. Like it's really bad for everyone involved" (Baker, 2014: 26). ${ }^{3}$

As the play unfolds Baker's interest lies increasingly on the closer bonds characters slowly, clumsily, hesitantly forge and on how miscommunication and misunderstandings fray their uneven triangular relationship, as both men project their fears and fantasies on the unattainable and "sexually magnetic" (Baker, 2014: 5) female

\footnotetext{
${ }^{3}$ The second definition of the entry "precarious" of the Oxford English Dictionary refers specifically to a line of argument "insecurely founded or reasoned, doubtful, dubious" (OED, "precarious" 2020).
} 
projectionist. Characters "have not yet made up their minds about who they are" (Yue, 2016: 57), but they sometimes forget to act cool and they openly reveal their problems and disappointments. Private confessions, though, are always made to just another person, eventually leading to unexpected tensions and betrayals in the group. Thus, amidst sweeping, Sam tells Avery that he will be off for a whole weekend to attend the wedding of his older retarded brother. Then, when he is away, in the memorable scene closing Act One, where Avery and Rose stay at the theatre overnight on Friday to watch movies and party, Rose's failed attempt at seducing Avery as they watch Sam Peckinpah's The Wild Bunch discloses that she is not a lesbian (as Sam had assumed), but is admittedly obsessed with sex. A paralyzed Avery confesses instead to having attempted suicide just a year earlier. Only the intimation of their own vulnerabilities makes these characters closer to each other. But while the recognition of a shared ontological precariousness brings them together, their precarity will eventually take their relationship apart.

Baker's slow-paced, meticulous portrayal of the characters interpersonal relationships is of great relevance for a critical assessment of her depiction of precarity and class awareness in The Flick. This becomes much clearer in Act Two, when the working scenario shifts at once imperceptibly, if precarity is understood as "an ongoing (structurally) economic problem" (Puar et al., 2012: 166), and dramatically in affective terms as the theatre is sold, and under new management, shifts to digital projection. Nothing changes and everything changes. At the beginning of this act, characters are blindly obsessed by their personal disappointments. Sam confesses to Rose that he is in love with her. For Avery, in turn, that Steve should sell a cinema that is literally falling to pieces, with chunks of tile falling from the ceiling, would "be like one of the saddest things of all time" (Baker, 2014: 75) and he might even quit. A skeptical Rose does not really care that her job become obsolete and feels at odds by Sam's confession. While Avery's deeply-felt concern with the vanishing of film projections clearly distances him from the other two workers, what eventually makes them grow apart is, however, a class awareness that does only transpire when their Dinner Money scam is unveiled by the new manager and, with it, the most pernicious effects of structural economic precarity exposed and magnified under the lights now gone fluorescent in the new North Brookfield "Venue" (Baker, 2014: 97). As Avery had foreboded, the new manager believes it to be his sole responsibility, but as he had not expected, his fellow employees will refuse to confess, under the pressure of a potential dismissal, that the stealing was a collective fraud. Rose's argument is that neither she, who has "like 20,000 dollars in student loans to pay off and [her] mom is a secretary", nor Sam, who "is 35 and he lives in a shitty attic above his crazy parents", have a "rich dad" teaching at Clark who could support them: "this isn't like a job we have while we go to college. This is what we like-feed ourselves with" (Baker, 2014: 104; her emphasis).

\section{CONCLUSION}

The way Baker stages Avery's foreshadowed dismissal at the end of The Flick underscores how her peculiar peripheral, behind-the-scenes, indirect vision affects her engagement with structural contingency and normalized precarity. The playwright avoids showing the event itself to look at the aftermath instead and, by circumventing it, it becomes oddly undramatic and uneventful. Avery fails or abstains from convincing Rose, as he timidly stammers that his father "isn't rich" (Baker, 2014: 104), that his being financially better off is just an assumption: living with his father and depending on him makes his position as precarious as that of his fellow workers. The ending of the play unabashedly shows that under systemic precarization all workers are easily replaceable: 
just as Avery took over from one Roberto who had joined the Marines, he is later on replaced by a young man called Skylar. It is not clear whether a betrayed Avery's expectations, uttered in the last scene,-i.e., that in coming back some day to visit Massachusetts he will find there Sam sweeping up popcorn while he might be "living in Paris or something" (Baker, 2014: 114)—should be taken for granted. The play seems to suggest, nonetheless, that Avery's cultural capital, an immaterial and relational good, clearly differentiates him from Sam and Rose. Avery's relationship with cinema is obsessive but he understands his life through its lens: his knowledge is clearly a good that had the power to transform the space characters shared and bridge their differences.

Baker's drama, like the theatre of today's major dramatists is post-tragic insofar as it refrains from "from instituting itself as a place for consensus and restoration of order, aiming rather to expose...unhealed fractures" (Angel-Perez, 2014: 125). It shows a precarious aesthetic that deals with the material world of precarity and pleads for its alleviation, but does not so explicitly. In this sense The Flick qualifies as a "precarious text" that "eschews didacticism. Its textual mode is fragmented, jagged, and therefore unsettling. This puts its intended effect at risk of failure, which is to say, its effect is unpredictable" (Lemke, 2016: 19). On the one hand, this can be seen in the way the prolonged, minutely crafted anti-dramatic witnessing of precarious livelihoods sparked divergent emotional reactions among spectators. The very opacity of the everyday gibberish speech of the characters, hardened into impersonal and fossilized clichés is often, throughout the play, a hindrance to genuine communication. On the other hand, however, Baker's virtuosic construction of complex, flawed yet lovable characters allows that these members of the precariat may not be seen as victims, but as humans thriving and adapting to the ordinary as an impasse shaped by crisis, one that can induce a poetic, immanent world making.

Sam, Avery and Rose's faltering voices reflect their failure at transmuting together their discontent into a common class awareness that could be transformational (Standing, 2018). Nonetheless, the intertwining of private betrayals and economic precarity that separates them eventually brings forth as well an opening for new visions of possibility and, perhaps, personal transformation. Theirs is a bittersweet ending. In the play's final scene, in which, now in street clothes, Avery returns to the movie theatre to collect a few reels and the old century projector that Sam has saved for him before it gets donated as scrap metal, Sam apologises. Avery admits that he "he had some kind of stupid idea that we were friends" but admits that realizing that he should not "expect things to turn out well in the end" (Baker, 2014: 114) has helped him a lot. Avery's embrace of a "postoptimistic" view of the world (Berlant, 2011), as seen above, stems from the destabilization of the conducts of life under precarization. This awareness, however, might have the potential of opening up new modes of living with ongoing crisis, uncertainty and vulnerability.

\section{REFERENCES}

Adiseshiah, Siân and Louise LePage (eds.). 2016. Twenty-First Century Drama: What Happens Now. London: Palgrave Macmillan.

Allison, Anne. 2016. "Precarity: commentary by Anne Allison." Cultural Anthropology, Curated Collections: Precarity. https://culanth.org/curated_collections/21precarity/discussions/26-precarity-commentary-by-anne-allison.

Angel-Perez, Elizabeth. 2014. "II am the Place of my Wound': Precarious Lives on the Contemporary English Stage". In Borte, B. and Regard, F. (eds.) Narrating Precariousness: Modes, Media, Ethics. Heidelberg: Winter, 125-132. 
Angelaki, Vicky. 2017. Social and Political Theatre in 21st-Century Britain. London: Bloomsbury.

Aragay, Mireia and Martin Middeke (eds.). 2017. Of Precariousness: Vulnerabilities, Responsibilities, Communities in 21st-Century British Drama and Theatre. Berlin: De Gruyter.

Aston, Elaine. 2016. "Room for realism?” In Adiseshiah, S. and LePage, L. (eds.), Twenty-First Century Drama: What Happens Now. London: Palgrave Macmillan, $17-35$.

Baker, Annie. 2012. The Aliens. In The Vermont Plays. New York: Theatre Communications Group.

Baker, Annie. 2014. The Flick. London: Samuel French.

Bennett, Susan. 1990. Theatre Audiences: A Theory of Production and Reception. London and New York: Routledge.

Berlant, Lauren. 2011. Cruel Optimism. Durham: Duke University Press.

Bigsby, Christopher. 2017. Twenty-First Century American Playwrights. Cambridge: Cambridge UP.

Bigsby, Christopher. 2020. Staging America. London: Methuen Drama.

Butler, Judith. 2004. Precarious Life: The Powers of Mourning and Violence. London: Verso.

Butler, Judith. 2012. "Precarious Life, Vulnerability, and the Ethics of Cohabitation." Journal of Speculative Philosophy 26.2: 134-151.

Butler, Judith. 2015. "Foreword". In Lorey, I., State of Insecurity: Government of the Precarious. London, New York: Verso, vii-xi.

Butler, Thomas. 2014. "Friends Dying Before Our Eyes in Annie Baker's The Aliens". In Herren, G. (ed.), Text and Presentation,179-191.

Cayer, Jennifer. 2011. "Her Town: Annie Baker's Americans". Journal of American Drama and Theatre, 23.3: 31-55.

D'Amour, Lisa. 2011. Detroit: A Play. New York: Faber and Faber.

"Drama". 2020. The Pulitzer Prizes. https://www.pulitzer.org/prize-winners-bycategory/218.

Faisst, Julia. 2017. "Moving In and Out, Up and Down: Real Estate in Twenty-First Century Drama". In Hahn, B. and Schmidt, K. (eds.), Inequality in America: Interdisciplinary Perspectives. Heidelberg: Universitätsverlag, 113-124.

Fernández-Caparrós, Ana; Anna M. Brígido Corachán. 2017. "Introduction: $\mathrm{Re} /$ Presentations of Crisis in 21st Century U.S. Literature and Culture". Studies in the Literary Imagination 50.1: v-xx. DOI: 10.1353/sli.2017.0002

Fisher-Lichte, Erika. 2016. "The Art of Spectatorship." JCDE, 4.1: 164-179.

Fragkou, Marissia. 2018. Ecologies of Precarity in Twenty-First Century Theatre: Politics, Affect, Responsibility. London: Bloomsbury.

Healy, Patrick. 2013. "The Flick Prompts an Explanation From Playwrights Horizons." Arts Beat New York Times Blog, March 25. https://artsbeat.blogs.nytimes.com/2013/03/25/the-flick-prompts-an-explanationfrom-playwrights-horizons/

Heller, Nathan. 2013. "Just Saying." The New Yorker, 25 February.

Hoby, Hermione. 2016. "From Pulitzer to popcorn: why Annie Baker is making the theatre world pause for thought.". The Guardian, April 1.

https://www.theguardian.com/stage/2016/apr/01/pulitzer-popcorn-playwrightannie-baker-critics-pause-thought

Hudes, Quiara Alegría. 2012a. Elliot, A Soldier's Fugue. New York: Theatre Communications Group. 
Hudes, Quiara Alegría. 2012b. Water by the Spoonful. New York: Theatre Communications Group.

Joseph, Rajiv. 2010. Gruesome Playground Injuries; Animals Out of Paper; Bengal Tiger at the Baghdad Zoo: Three Plays. New York: Soft Skull.

Kane, Leslie. 1984. The Language of Silence: On the Unspoken and the Unspeakable in Modern Drama. London and Toronto: Associated University Press.

Karam, Stephen. 2015. The Humans. New York: Theatre Communications Group.

Kasmir, Sharrin. 2018. "Precarity." In The Cambridge Encyclopedia of Anthropology. F. Stein, S. Lazar, M. Candea, H. Diemberger, J. Robbins, A. Sanchez \& R. Stasch. (eds) http://doi.org/10.29164/18precarity

Lemke, Sieglinde. 2016. Inequality, Poverty, and Precarity in Contemporary American Culture. Palgrave Macmillan.

Lorey, Isabell. 2015. State of Insecurity: Government of the Precarious. Translated by Aileen Derieg. London, New York: Verso.

Majok, Martina. 2019. Cost of Living. London: Nick Hern Books.

Mohler, Courtney; McMahon, Christina; and Román, David. 2016. "Three Readings of Reading, Pennsylvania: Approaching Lynn Nottage's Sweat and Douglas Carter Beane's Shows for Days." Theatre Journal 68.1: 79-94.

Nottage, Lynn. 2017. Sweat. New York: Theatre Communications Group.

Obama, Barack. 2009. "President Barack Obama's Inaugural Address." The WHITE HOUSE President Obama, January 21. https://obamawhitehouse.archives.gov/blog/2009/01/21/president-barack-obamasinaugural-address.

Obama, Barack. 2013. "Remarks by the President on Economic Mobility." The WHITE HOUSE President Obama, December 4. https://obamawhitehouse.archives.gov/the-press-office/2013/12/04/remarkspresident-economic-mobility

Paulson, Michael. 2020. "Straining From Shutdowns, Theaters Ask Playwrights to Return Payments". The New York Times, March 18. https://www.nytimes.com/2020/03/18/theater/lynn-nottage-annie-bakercoronavirus.html

Piepenburg, Erik. 2013. "Six Movies That Helped Lead a Playwright From the Cineplex to the Stage". The New York Times, April 3. https://nyti.ms/14JcPDb

“precarious, adj.". OED Online. September 2020. Oxford University Press. https://www.oed.com/view/Entry/149548?redirectedFrom=precarious\& (accessed October 09, 2020).

"precarity, n.". OED Online. September 2020. Oxford University Press. https:/www.oed.com/view/Entry/64050894?redirectedFrom=precarity (accessed October 09, 2020).

Puar, J. et al. 2012. "Precarity Talk: A Virtual Roundtable with Lauren Berlant, Judith Butler, Bojana Cveji, Isabell Lorey, Jaspir Puar, and Ana Vujanovi”. The Drama Review, 56 (4): 163-77.

Ridout, Nicholas and Rebecca Schneider. 2012. "Precarity and Performance: An Introduction". TDR: The Drama Review 56.4: 5-9.

Ruhl, Sarah. 2006. Eurydice. In The Clean House and Other Plays. New York: Theatre Communications Group.

Ruhl, Sarah. 2008. Dead Man's Cell Phone. New York: Theatre Communications Group.

Shinn, Christopher. 2006. Dying City. London: Methuen. 
Standing, Guy. 2012. “The Precariat: From Denizens to Citizens?”. Polity, 44.4: 588608.

Standing, Guy. 2018. “The Precariat: Today’s Transformative Class?” Development 61: $115-121$.

Wallace, Naomi. 2016. No Such Cold Thing. New York: Broadway Play.

Wolcott, James. 2015. "Why the Audiences Who Walked Out The Flick Made a Terrible Mistake". Vanity Fair, June 2.

Yue, Genevieve. 2016. "Google Hangout With Annie Baker, Playwright 1/25/16, 2:33 PM.” Film Quarterly, 59.4: 57-64. 